\title{
ZMAGANIA METODOLOGA Z EMPIRIĄ. POZYTYWISTYCZNA SOCJOLOGIA JAKUBA KARPIŃSKIEGO ${ }^{1}$
}

\author{
Jakub Bazyli Motrenko
}

Uniwersytet Warszawski

Jakub Karpiński (1940-2003) był znakomitym metodologiem socjologii ${ }^{2}$. Zgodnie z terminologia szkoły lwowsko-warszawskiej metodologia była refleksją nad podstawami nauki, a nie zbiorem technik badawczych jak sondaż, wywiady grupowe czy obserwacja uczestnicząca (Woleński 1985: 254). Dziś frankofoni powiedzieliby, że Karpiński uprawiał epistemologię socjologii, Anglosasi - filozofię nauk społecznych (Berthelot 2000: 8, zob. np. Berthelot 2001, Cuin 2000, Hollis 1994, Rosenberg 1995). Metoda nie zawsze jednak daje klucz do poznania.

Przedmiotem analizy tego artykułu jest naukowy program badawczy ukonstytuowany przez Karpińskiego w jego najważniejszej książce so-

\footnotetext{
${ }^{1}$ Praca nad artykułem została sfinansowana ze środków Narodowego Centrum Nauki przyznanych na podstawie decyzji numer DEC-2012/05/N/HS6/03944. Dziękuję profesorowi Antoniemu Sułkowi oraz dwóm anonimowym recenzentom za uwagi do pierwszej wersji tekstu. Jeśli nie uwzględniłem ich wszystkich, to tylko dlatego, że wymagają napisania nowych studiów, a nie rozbudowywania, i tak już obszernego, niniejszego artykułu.

${ }^{2}$ Stwierdzenie to wymaga relatywizacji z perspektywy dzisiejszych badań nad nauką. Duży i oryginalny dorobek Karpińskiego w tym zakresie jest jednak niewątpliwy. Należy wymienić artykuły (np. Karpiński 1962, 1963, 1965, 1976), również te zebrane w dwóch zbiorach (Karpiński 1989, 1992), monografię poświęconą przyczynowości (Karpiński 1985) i podręcznik Wprowadženie do metodologii nauk społecznych (Karpiński 2006). Sądzę, że metodologia Karpińskiego dobrze wpisuje się w panujący obecnie klimat badań z zakresu filozofii nauk społecznych w tradycji analitycznej. Jedynej „inwentaryzacji” poglądów metodologicznych Karpińskiego dokonał Jacek Jadacki (2013), postulując jednocześnie ich „systematyzację” w przyszłości. Pozostaje mi tylko przyłączyć się do tego apelu, sugerując, aby przyszła synteza objęła swoim zasięgiem całą formację wybitnych badaczy prowadzących w Polsce metarefleksję nad naukami społecznymi po drugiej wojnie światowej. W nurt ten wpisują się m.in. Maria i Stanisław Ossowscy, Stefan Nowak, Andrzej Malewski, Klemens Szaniawski, Edmund Mokrzycki, Julia Sowa, Adam Podgórecki, Jerzy Topolski, Leszek Nowak, Jerzy Kmita, Piotr Sztompka czy Jacek Szmatka.
}

\section{/ $212 \quad$ STANRZECZY 2[9]/2015}


cjologicznej Ustrój komunistyczny w Polsce. Był to projekt, który kwalifikuję jako pozytywistyczny. Zamiast jednak szukać tego, co łączy go z podobnymi przedsięwzięciami socjologicznych scjentystów, odkrywam naukowy idiolekt Karpińskiego, który stanowił ważny element krajobrazu polskiej socjologii lat 70. i 80.: na poziomie sytuacji retorycznej, metody i ontologii. Podejmuję próbę rekonstrukcji epistemologii programu empirycznego, niewypowiedzianej przez Karpińskiego explicite. Sformułowana zostanie również odpowiedź na pytanie, dlaczego projekt ten nie stał się w sensie Imrego Lakatosa programem postępowym, kontynuowanym i rozwijanym przez innych badaczy.

Ustrój komunistyczny w Polsce $e^{3}$ doczekał się trzech wydań i wielu wznowień. Spośród książek Karpińskiego dotyczących PRL-u była ona najbardziej kompleksową i „socjologiczną” analizą ówczesnego systemu społecznego, pisaną z zaangażowaniem, ale i przy zachowaniu naukowego dystansu (por. Grabowska 2006: 347). Książka stała się materiałem dla niniejszego artykułu; stanowi ona synekdochę socjologii Karpińskiego.

\section{/// Retoryka encyklopedyczna}

Język nauk niededukcyjnych realizuje przede wszystkim funkcje semantyczne, tzn. składa się ze zdań obdarzonych sensem empirycznym, pozwalającym rozstrzygnąć o ich prawdziwości (por. Ossowski 1967: 291-297). Słownik zawiera nazwy obiektów, własności i relacji istniejących w rzeczywistości; ich zestawienie w syntaktycznie poprawnie sformułowanych zdaniach tworzy modele rzeczywistości. Karpiński (2006: 21 oraz rozdział IV pt. Jezyk nauki) podkreśla, że swoisty charakter języka nauki stanowi jej cechę dystynktywną. Biorąc pod uwagę pragmatykę języka, powiedzielibyśmy, że język nauki różni się od potocznego koncentracją na funkcji poznawczej, czyli przekazywaniu informacji.

Pozytywistyczna wizja języka nauki nie pozostawia wiele miejsca na badanie jego funkcji pragmatycznych. Karpiński (2006: 123) za Ajdukiewiczem (1960: 215-216) widział wymiar pragmatyczny w uənawaniu pewnych typów zdań w sposób bezwarunkowy (na mocy znaczenia wyrazów w danym słowniku) lub warunkowy (na mocy uznania innych zdań lub

\footnotetext{
${ }^{3}$ Niniejszy tekst poświęcony jest jednej książce, która w różnych wydaniach przyjmowała nie tylko odmienne tytuły, ale różniła się także treścią: pewne rozdziały i podrozdziały znikały w dalszych wydaniach, zmieniał się kształt stylistyczny zdań, dodawane były jedne przykłady, a usuwane inne. Cytaty będą pochodziły z najnowszego wydania z 2005 roku. Posługiwał się będę tytułem drugiego i trzeciego wydania - Ustrój komunistyczny w Polsce - odnosząc się do, jak powiedziałby Saul Kripke (2001), ,sztywnego desygnatora”.
} 
wobec pewnych doświadczeń podmiotu). Badacza interesuje nie tylko porządek dowodzenia jako relacji między zdaniami, ale również porządek ugruntowania przekonań, np. w pewnych danych zmysłowych. Badanie retoryki tekstu naukowego stawia sprawę w sposób bardziej radykalny. Socjologowie analizują język nauki jako fenomen, który w różnych miejscach i czasach przyjmował specyficzne środki w celu przekonania publiczności o prawomocności wyrażanych tez. Badanie retoryki przesuwa zainteresowanie językiem nauki z modelowania rzeczywistości i dowodzenia w wymiar argumentacji (Toulmin 2003), przyjętego w danej epoce stylu wyrażania myśli (Douglas 1978), a nawet perswazji (Latour i Fabbri 1977).

Nowożytna nauka zinstytucjonalizowała odrębny styl komunikacji wyników badań (Shapin 2010). Karpiński z pewnością zgodziłby się, że język nauki (rozumianej jako instytucja społeczna) jest językiem konwencjonalnym w tym sensie, że podlega historycznej ewolucji oraz korzysta z różnych narzędzi retorycznych w celu uprawomocnienia swoich twierdzeń. Zauważa na przykład, że w naukach społecznych jasność, precyzja i jednoznaczność są charakterystyczne dla jednych badaczy i kolektywów, gdy dla innych już nie (Karpiński 2006: 121). Karpiński nie zgodziłby się jednak, że środki retoryczne faktycznie decydują o legalności twierdzeń nauki (por. Berthelot 2008: 59-61). W pozytywistycznej metodologii nauki reprezentowanej przez Karpińskiego nie mieściły się analizy pragmatyki języka: sa zadaniem historyków, socjologów czy językoznawców autonomicznym wobec epistemologicznego punktu widzenia. O legalności twierdzeń nauki (rozumianych jako zbiór dobrze uzasadnionych twierdzeń) decydować ma przede wszystkim trafne modelowanie za pomocą środków językowych dziedziny badań (prawdziwość), ale również np. moc wyjaśniająca teorii czy oszczędność pojęciowa (Karpiński 2006: 293-301).

Twierdzę, że zasadne jest analizowanie wymiaru pragmatycznego języka nauki nie tylko przy badaniach socjologicznych czy historycznych (tj. badaniach norm i instytucji nauki), lecz także podczas prowadzenia refleksji epistemologicznej (tj. w badaniach wiedzy). Nawet jeśli sytuacja retoryczna nie determinuje przyjęcia przez wspólnotę naukową twierdzeń jako pewnych, to praktycznie warunkuje kryteria legalizacji bycia dowodem na rzecz przyjętych tez. Karpiński zresztą zdawał sobie $z$ tego sprawę: wiele miejsca poświęcił w swojej twórczości antydogmatyzmowi, dla którego konieczna jest wolności słowa (zob. tom Nie być w myśleniu posłusznym (Karpiński 1989)). Choć sam był myślicielem niezależnym, to kontekst, w którym mogły funkcjonować jego książki, determinował ich los, formę i treść. 
Spektrum środków językowych socjologa jest bardzo szerokie: od zestawień tabelarycznych i równań regresji po poetyckie eseje. Socjologowie scjentyści trzymali się bliżej pierwszego końca tego zakresu, choć posługiwali się nie tylko językiem ilościowym, ale - jak sam Karpiński - również kategoriami jakościowymi. Pozytywiści za pomocą środków stylistycznych podkreślają dekontekstualizację wiedzy: realny podmiot zostaje zastapiony podmiotem epistemicznym, kierującym się regułami uniwersalnej metody naukowej. Jak zauważa Joseph Gusfield (1976: 17), „,styl braku stylu jest stylem nauki”. Badacz przekonuje swoja publiczność, że wyniki badań nie sa literatura piękna, a ich uzasadnienie wytworem sposobu prezentacji. Karpiński przyjmował strategię zwięzłości i precyzji (,im krócej, tym lepiej”miał radzić piszącym (Sułek 2006: 351)). Antoni Sułek (2006: 354) określa go mianem „mistrza słowa naukowego".

Poniżej skupię się na retoryce nie jako stylu pisarstwa Karpińskiego, ale jako relacji między autorem i jego czytelnikami. Każdy komunikat wyrażany jest w pewnym kontekście społecznym, do kogoś i przez kogoś; komunikaty nauki nie są od tej reguły wyjątkiem. Rekonstrukcja sytuacji komunikacyjnej, odtworzenie relacji między mówcą a jego audytorium, autorem i czytelnikami jest dla tej analizy sprawą kluczową. Pozwoli ukazać cel pisanych przez Karpińskiego tekstów oraz odkryć środki najlepiej prowadzące do jego realizacji.

Kontekst wydawniczy decyduje, jakie są warunki przyjęcia tekstu do druku, kim będą czytelnicy, jaka jest relacja między autorem a czytelnikami, co należy do zasobu wiedzy pewnej, a co wciąż negocjowanej, jakie sa kryteria oceny wartościowości pracy (por. Gusfield 1976: 18; Latour i Fabbri 1977: 83). W Polsce komunistycznej kontekst wydawniczy był kontekstem politycznym. Drukować można było oficjalnie tylko to, na co była zgoda władz.

Pierwszymi czytelnikami Ustroju komunistycznego... byli polscy inteligenci śledzący publikacje paryskiej „Kultury”. Jak konstatował Karpiński (1988: 123): „książki Instytutu Literackiego były w Polsce znane, ale niewiele osób zwróciło na «Nowy ustrój» uwagę, choć, jak sądzę, były tam myśli, które mogły zaciekawić socjologów, starających się opisać społeczeństwo polskie jako całość". Przy kolejnych wznowieniach (fragmentów książki i in extenso (zob. Tabela 1)) korzystano z dobrodziejstw rozwijającego się drugiego obiegu wydawniczego. Co za tym idzie, czytelnikami przestali być tylko inteligenci, a została krytyczna wobec systemu opinia publiczna ukształtowana w okresie Solidarności (por. statystyki dotyczące przyrostu pracy niezależnej w: Wróblewski 2010). Wreszcie, ostatnie, ponownie poprawio- 
ne wydanie miało stać się rozprawą habilitacyjną Karpińskiego (Koźmiński 2005). Widocznymi znakami „unaukowienia” pracy jest zwiększenie liczby referencji, stworzenie systematycznego zapisu bibliograficznego czy krytyczny wstęp Marcina Kuli. Książka dostałaby szansę na włączenie do zasobów kognitywnych pola nauki i bycie poddaną ocenie zgodnie z jego normami. Sama publikacja z 2005 roku, już po śmierci Karpińskiego, nie była jednak powodowana racjami poznawczymi, ale raczej reminiscencyjnymi. Jak podkreśla Koźmiński (2005), jest to książka wyjątkowa nie tylko ze względu na treść, ale i osobę autora. Kula (2005: 7-8) akcentuje wartość prac Karpińskiego w pierwotnym kontekście, mniej jest przekonany do wagi tych dzieł w Polsce po roku 1989. Docenia co prawda podejście modelowe, szeroka perspektywę porównawczą, bogate odwołania do literatury ogólnej itd., ale z przedmowy przebija dystans i potrzeba dopowiedzenia tego, czego Karpiński sam nie powiedział.

Książkę naukową - jeśli nie jest klasyką - wznawia się rzadko: dzieje się to, gdy nakład poprzedniego wydania został wyczerpany, a dzieło przeszło próbę czasu i postrzegane jest jako ważne dla aktualnych debat w ramach dyscypliny. Czytelnikami takich prac są osoby obdarzone reputacja w ramach pola nauki, eksperci w swoich dziedzinach. Kolejne wznowienia Ustroju komunistycænego... nie funkcjonowały w ramach pola socjologii, lecz w polu inteligencji oraz opinii publicznej krytycznej wobec systemu komunistycznego. Reguły działania w tych polach są odmienne: różni je nadrzędny cel, reguły akceptacji twierdzeń, zalegitymizowane dane oraz typ relacji między czytelnikiem a autorem (zob. Tabela 2).

Instytucje pola nauki wypracowały mechanizmy ewaluacji twórczości uczonych: wydawnictwa naukowe posiadają redaktorów tematycznych i komitety wydawnicze, druk uzależniony jest od opinii recenzentów. Kolejne podziemne wydania Ustroju komunistycznego... świadczą o tym, że ścieżka publikacji książki Karpińskiego była charakterystyczna dla pism politycznych, a nie dzieła naukowego. Ustrój komunistyczny... nie stał się elementem procesu formowania konsensusu naukowego: kolejne wznowienia świadczą o rozwoju podziemnych oficyn wydawniczych, a nie uznaniu naukowej wartości tekstu. Obieg, w którym książka funkcjonowała, nie sprzyjał rzetelnej ocenie ze względu na wartości poznawcze. Publikacja ukazywała się z intencją realizacji dobra pozaprofesjonalnego: walki z systemem komunistycznym. Stawką była przemiana świadomości czytelników, dostarczenie intelektualnej broni przeciwko systemowi, a nie prowokowanie (i przetrwanie) krytycznej dyskusji. 


\begin{tabular}{|c|c|c|}
\hline $\begin{array}{l}\text { TYTUŁ } \\
\text { I AUTOR } \\
\text { Z OKŁADKI }\end{array}$ & $\begin{array}{l}\text { ROK, } \\
\text { WYDAWCA, } \\
\text { MIEJSCE } \\
\text { WYDANIA }\end{array}$ & UWAGI \\
\hline $\begin{array}{l}\text { Ewolucja cュy } \\
\text { rewolucja, Marek } \\
\text { Tarniewski }\end{array}$ & $\begin{array}{l}\text { 1975, Instytut Lite- } \\
\text { racki, Paryż }\end{array}$ & $\begin{array}{l}\text { wydanie pierwsze } \\
\text { tytuł nadany przez wydawcę } \\
\text { (Karpiński 1988: 123) }\end{array}$ \\
\hline $\begin{array}{l}\text { Nowy ustrój i ewo- } \\
\text { lucja, Marek Tar- } \\
\text { niewski }\end{array}$ & $\begin{array}{l}\text { 1979, Biblioteka } \\
\text { „Głosu”, Warszawa }\end{array}$ & $\begin{array}{l}\text { wybrane podrozdziały z pierwszego } \\
\text { wydania w tym prawie cały rozdział } \\
\text { pt. Czynniki prz̨emian } \\
\text { podział pracy na dwie części: } \\
\text { I. Nowy ustrój i II. Ewolucja }\end{array}$ \\
\hline $\begin{array}{l}\text { Ewolucja czy } \\
\text { rewolucja, Marek } \\
\text { Tarniewski }\end{array}$ & $\begin{array}{l}\text { 1981, Wydawnictwo } \\
\text { „Alfa”, Kraków }\end{array}$ & $\begin{array}{l}\text { przedruk rozdziału drugiego z wyda- } \\
\text { nia pierwszego pt. Własność, państwo } \\
\text { ipartia } \\
\text { wydanie kieszonkowe }(9 \times 14 \mathrm{~cm})\end{array}$ \\
\hline $\begin{array}{l}\text { Nowy ustrój i re- } \\
\text { wolucja, Marek } \\
\text { Tarniewski }\end{array}$ & $\begin{array}{l}\text { 1983, Oficyna Wol- } \\
\text { nego Słowa, War- } \\
\text { szawa }\end{array}$ & $\begin{array}{l}\text { przedruk z drobnymi poprawkami } \\
\text { rozdziału trzeciego z wydania pierw- } \\
\text { szego pt. Organizacja społeczeństwa, elita } \\
\text { władzy }\end{array}$ \\
\hline $\begin{array}{l}\text { Ustrój komunistycz- } \\
\text { ny w Polsce, Jakub } \\
\text { Karpiński }\end{array}$ & $\begin{array}{l}\text { 1985, „Aneks”, Lon- } \\
\text { dyn }\end{array}$ & wydanie drugie \\
\hline $\begin{array}{l}\text { Ustrój komunistycz- } \\
\text { ny w Polsce, Jakub } \\
\text { Karpiński }\end{array}$ & $\begin{array}{l}\text { 1986*, Wydawnictwo } \\
\text { Grupy Polityczne } \\
\text { „Wola”, Warszawa }\end{array}$ & $\begin{array}{l}\text { przedruk trzech pierwszych rozdziałów } \\
\text { z wydania drugiego pt. Władza i wła- } \\
\text { snośc, Organizacja oficjalna i aparat władzy, } \\
\text { Rzqdzqcy i rzqdzeni } \\
\text { wydanie kieszonkowe }(9 \mathrm{x} 14 \mathrm{~cm})\end{array}$ \\
\hline $\begin{array}{l}\text { Ustrój Komunistycz- } \\
\text { ny w Polsce, Jakub } \\
\text { Karpiński }\end{array}$ & $\begin{array}{l}\text { 1987*, Biblioteka } \\
\text { Wolnego Głosu } \\
\text { Ursusa „Myśl”, War- } \\
\text { szawa }\end{array}$ & \\
\hline $\begin{array}{l}\text { Ustrój komuni- } \\
\text { stycrny w Polsce, } \\
\text { Jakub Karpiński }\end{array}$ & $\begin{array}{l}\text { 2005, Wyższa Szko- } \\
\text { ła Przedsiębiorczo- } \\
\text { ści i Zarządzania } \\
\text { im. Leona Koźmiń- } \\
\text { skiego, Warszawa }\end{array}$ & wydanie trzecie \\
\hline
\end{tabular}

Tabela 1. Kolejne wydania i wznowienia książki Jakuba Karpińskiego Ustrój komunistyczny w Polsce w języku polskim.

* Informacja katalogowa (Katalog Biblioteki Narodowej), brak daty wydania na publikacji. 


\begin{tabular}{|l|l|l|l|l|}
\hline & $\begin{array}{l}\text { nadrzędny } \\
\text { cel }\end{array}$ & $\begin{array}{l}\text { reguły } \\
\text { akceptacji } \\
\text { twierdzeń }\end{array}$ & $\begin{array}{l}\text { zalegitymi- } \\
\text { zowane dane }\end{array}$ & $\begin{array}{l}\text { typ relacji } \\
\text { czytelnik- } \\
\text { autor }\end{array}$ \\
\hline $\begin{array}{l}\text { pole } \\
\text { nauki }\end{array}$ & $\begin{array}{l}\text { formowanie } \\
\text { konsensusu } \\
\text { wokół twier- } \\
\text { dzeń pewnych, } \\
\text { tworzenie } \\
\text { postępowych } \\
\text { programów } \\
\text { badawczych }\end{array}$ & $\begin{array}{l}\text { logiczne zdań, } \\
\text { ugruntowanie } \\
\text { tez w danych, } \\
\text { koherencja } \\
\text { interpretacji }\end{array}$ & $\begin{array}{l}\text { zobiektywizo- } \\
\text { wana sieć fak- } \\
\text { tów i tekstów }\end{array}$ & $\begin{array}{l}\text { egacja } \\
\text { egalitarna, } \\
\text { peer review }\end{array}$ \\
\hline $\begin{array}{l}\text { pole } \\
\text { opinii } \\
\text { publicz- } \\
\text { nej }\end{array}$ & $\begin{array}{l}\text { formułowanie } \\
\text { programu } \\
\text { politycznego } \\
\text { zdolnego for- } \\
\text { mować posta- } \\
\text { wy i pobudzać } \\
\text { do działania }\end{array}$ & $\begin{array}{l}\text { zgodność } \\
\text { z systemem } \\
\text { normatywnym }\end{array}$ & $\begin{array}{l}\text { bezpośrednie } \\
\text { doświadczenie } \\
\text { podzielane } \\
\text { przez wspól- } \\
\text { notę w danym } \\
\text { miejscu } \\
\text { i czasie }\end{array}$ & $\begin{array}{l}\text { relacja } \\
\text { autorytetu, } \\
\text { wykład } \\
\text { ex cathedra }\end{array}$ \\
\hline
\end{tabular}

Tabela 2. Normy funkcjonowania dzieła w polach nauki i opinii publicznej.

Kontekst odkrycia pozostaje dla ważności analiz neutralny, istotny jest bowiem kontekst uzasadnienia. Tak też sprawę widział Karpiński (1975: 7, 1988: 123), dla którego książka stanowiła opis ustroju i jego ewolucji, a dopiero przy pewnych założeniach, jak stwierdza, można było wnioskować o programie zmian. Jest to jednak nazbyt uproszczona wizja procesu włączania hipotez naukowych do wiedzy pewnej: obrona tez jest procesem rozciagniętym w czasie i ma charakter kolektywny.

Karl Popper (2002: 249 i nast., 2012: 29-33) wprowadził cenną intuicję: teoria, która potrafi sprostać surowym sprawdzianom, która ,wykazuje się żywotnością", posiada wyższy stopień potwierdzenia (koroboracji). Co prawda, nie mówi to nic o przyszłych zachowaniach teorii, ale stawia w centrum działania naukowego konstruowanie krytycznych testów hipotez. Potwierdzenie teorii jest funkcją kolejnych testów, z których wychodzi ona obronną ręką; siłą rzeczy koroboracja jest czasochłonna, praktycznie niemożliwa do wykonania w jednym momencie. Z kolei Ludwik Fleck (1986: 130, passim) podkreślał nadto kolektywny charakter myślenia: styl myślowy jest struktura powstająca na poziomie kolektywu w wyniku konfrontacji rozmaitych indywidualnych wysiłków. Podobne przekonania, choć wyra- 
żone w formie swobodnej, można zresztą znaleźć w opublikowanym przez Karpińskiego tekście Ossowskiego (1989: 169) o wolności słowa:

Zarówno psychologia twórczości, jak dzieje kultury stanowią arsenał dokumentów na rzecz tezy, że partenogeneza w sferze pomysłów twórczych jest równie rzadka jak w rozmnażaniu się istot żywych wyższego rzędu, a wielkość komunikujących się ze sobą nurtów daje najlepsze warunki zapładniania myśli. Dotyczy to pomysłów twórczych w nauce tak samo jak w filozofii i sztuce.

Książka Karpińskiego ani nie była poddana surowym testom, ani nie została włączona do sieci tekstów naukowych ${ }^{4}$. Istotna przeszkoda była sytuacja komunikacyjna: publiczność, do której docierały prace Karpińskiego, i kontekst, w którym jego dzieło funkcjonowało, determinowane przez czynniki polityczne, nie sprzyjały krytycznej analizie. Inne są reguły legalizacji dzieła naukowego, inne - politycznego. Czytelnicy Karpińskiego przyjmowali reguły akceptacji dzieła pochodzace spoza systemu normatywnego pola nauki.

Książki socjologiczne bada się ze względu na wynikanie wniosków $\mathrm{z}$ wysuwanych tez, ugruntowanie tez $\mathrm{w}$ danych empirycznych (zbieranych bezpośrednio lub prezentowanych przez innych badaczy), koherencję teoretycznej interpretacji itd. Tymczasem Ustrój komunistyczny... był wznawiany wielokrotnie, ponieważ demaskował system polityczny: tezy książki pozostawały w konflikcie z oficjalnym dyskursem partyjnym. Decydującym kryterium akceptacji była dla opinii publicznej użyteczność dzieła w konfrontacji ideologicznej. Opinia publiczna akceptuje książkę, kiedy pasuje ona do przyjętego systemu normatywnego. Również model relacji między autorem a opinia publiczna jest inny niż relacja autora z czytelnikami w polu nauki. Po pierwsze, dopuszcza w komunikacji oparcie się na niezobiektywizowanych przez naukę doświadczeniach. Po drugie, ustanawia relację autorytetu i wykład ex cathedra w miejsce relacji egalitarnej i krytycznej dyskusji.

Między czytelnikami Ustroju komunistycznego... a Karpińskim istniała wspólnota doświadczenia; razem żyli w pewnej rzeczywistości społecznej, dzielili wiedzę o życiu w ówczesnym systemie. Zdejmowało to z autora ciężar ugruntowywania wygłaszanych twierdzeń; miały one charakter sa-

\footnotetext{
${ }^{4} \mathrm{O}$ istnieniu problemowej recenzji napisanej przez Mirosławę Grabowską i Tadeusza Szawiela (,Zapis”, nr 6, artykuł podpisany inicjałami „G.S.”) dowiedziałem się tuż przed oddaniem tego numeru „Stanu Rzeczy” do druku. W miarę możliwości włączyłem uwagi czynione przez tych autorów do dalszego wywodu.
} 
mooczywisty. Nie było konieczne przedstawianie danych czy referencji do innych prac, bo jaka jest rzeczywistość, każdy widział. Czytelnicy łatwo przyjmowali tezy Karpińskiego, gdyż werbalizowały one ich intuicje. Książka Karpińskiego była odkrywcza w tym sensie, że ujawniała istotę komunizmu, którą czytelnicy już podskórnie wyczuwali ${ }^{5}$. Tłumaczy to też opóźnioną recepcję książki: dopiero w latach 80., po wybuchu Solidarności, czytelnicy zdali sobie sprawę z wielu cech systemu, o których Karpiński pisał już wcześniej. Subiektywnie stało się jasne, że system komunistyczny w Polsce był właśnie taki, jak pisał o tym Karpiński.

Weźmy pod rozwage typowy dla Ustroju komunistycznego... fragment dotyczący zasady monolityczności:

Osoby nie zgadzające się z poczynaniami władz partyjnych opuszczały niekiedy szeregi tej organizacji. Natomiast ich szanse wpływu na poczynania przywódców były niewielkie, właśnie wobec zakazu koalicji i działań grupowych. Konsekwencje tego zakazu były niekorzystne nawet dla realizacji niektórych celów kierownictwa partii. Zakaz niezależnych działań zbiorowych w PZPR utrudniał wypracowanie strategii i korygowanie błędów. W dodatku zakaz dyskusji i rozbieżności wewnątrzpartyjnych prowadził - ze względu na funkcje partii komunistycznej w całym ustroju - do negatywnych skutków o charakterze ogólnospołecznym. Zakaz ten bowiem obowiązywał w organizacji pełniącej szczególną rolę: w jej kierowniczych instancjach opracowywano i podejmowano decyzje dotyczące społeczeństwa w całości, a nie tylko tej właśnie organizacji (Karpiński 2005: 47-48).

Wyimek zawiera pozornie tylko dookreślające zwroty, takie jak „niekiedy”, „niewielkie”, „,niektóre”. Żadna z powyżej wypowiedzianych tez nie jest poparta odwołaniem do materiałów źródłowych czy innych publikacji. Brak jest również przykładów, które egzemplifikowałyby tezy ogólne. Nie wiemy, jakie osoby opuściły organizację, na podstawie czego stwierdza się posiadanie wpływu na działania przywódców, jakie miałyby być negatywne skutki ogólnospołeczne.

\footnotetext{
5 Trzeba zaznaczyć, że była to wówczas rzecz niebagatelna. Mirosława Grabowska i Tadeusz Szawiel (1978: 112-113) pisali w 1978 roku w recenzji: „Książka ta jasno pokazuje erozję naszego języka i jego zużycie przez język propagandy. Kto jeszcze spontanicznie, bez analitycznego wysiłku rozróżnia upaństwowienie od uspołecznienia? Czyż nie uwierzyliśmy, że państwo daje nam pracę i zarobki? I jeszcze do nas dokłada? A prawo, czy umiemy je jeszcze wnikliwie czytać i rozumieć? Lektura książki Tarniewskiego to w pewnym sensie ratowanie naszego języka”.
} 
W nauce naoczne świadectwa są obiektywizowane w danych, które moga podlegać wzajemnej konfrontacji, oraz w tekstach innych badaczy. Uprawomocnieniem działań historyka jest praca na źródłach. Minione zdarzenia są materializowane w notatkach służbowych, pamiętnikach, spisach, rachunkach, gazetach, fotografiach, artefaktach itd. Ekonomia tekstu Karpińskiego była charakterystyczna dla socjologa, a nie historyka (por. Berthelot 1996: 129-140). Nie zmienia to jednak faktu, że również teksty socjologiczne potrzebuja empirycznego ugruntowania. To, że socjolog zazwyczaj zajmuje się współczesnością, odejmuje pracy źródłowej. Przeprowadzenie dowodu wymaga jednak wytworzenia materiałów (wywiady, sondaże, eksperymenty, obserwacja, itp.) lub sięgnięcia po materiały wytwarzane przez inne instytucje (spisy powszechne, dane administracyjne itp.). Wspólnota doświadczenia zwalnia Karpińskiego z konieczności przytaczania empirycznych uzasadnień. Są one oczywiste dla każdego, kto żył w PRL-u.

Prace naukowe są sytuowane w kontekście innych dowodów, zobiektywizowanych w ramach wspólnoty badaczy. Rzadko do takich materiałów odwołuje się Karpiński. Na słabość tę - z punktu widzenia norm pola nauki - zwracal uwagę recenzent książki Karpińskiego Countdown. The Polish Upheavals of 1956, 1968, 1970, 1976, 1980... w „The American Political Science Review”: „brak bibliograficznych referencji, nawet odnośnie bezpośrednich cytatów, mocno ogranicza jej atrakcyjność dla wspólnoty uczonych" (Kanet 1982) ${ }^{6}$. Diagnozę tę można odnieść również do Ustroju komunistycznego...

Wspólnota doświadczenia wiąże się również z kanonem tekstów znanych każdemu czytelnikowi. Gdy kanon funkcjonuje, wówczas można odwoływać się do tekstów w sposób jedynie schematyczny. Odwołanie ma na celu przypomnienie czytelnikowi znanych treści, a nie rekonstrukcję argumentacji. Istotnym kontekstem polemicznym Karpińskiego była ideologia marksistowska. W typowym fragmencie stwierdza:

Ideolodzy partyjni posługiwali się niekiedy dość swoistym - po części normatywnym - pojęciem świadomości społecznej. Świadomościa społeczną nazywali mianowicie to, co ich zdaniem powinno się pojawić w świadomościach indywidualnych. Ideolodzy ci wspominali nawet o badaniu relacji między tak rozumianą świa-

\footnotetext{
${ }^{6}$ Trzy pierwsze rozdziały książki Countdown... stanowiły przedruk z wcześniejszych publikacji Karpińskiego; rozdzial pierwszy The Origins of the System stanowil przekład rozdziału pierwszego z pierwszego wydania Ustroju komunistycznego..., w kolejnych wydaniach usuniętego.
} 
domością społeczną a świadomościami indywidualnymi. Miało to polegać na sprawdzeniu, czy i w jakim stopniu ludzie przyswoili już sobie ten sposób myślenia i te treści, które ideolodzy im wyznaczyli (Karpiński 2005: 179).

Nie jest jasne, jacy ideolodzy i w jakich tekstach pisali tak o świadomości społecznej. Karpiński wypreparowuje esencję poglądów, nie przedstawia zaś szczegółowej rekonstrukcji argumentacji (por. Grabowska i Szawiel 1978: 113).

Dostęp do danych publicznych, archiwów i literatury był dalece ograniczony, w związku z tym Karpiński musiał opierać się jedynie na tym, co było ogólnodostępne: wyrywkowych danych publicznych o różnej wartości, wyimkach gazetowych, codziennych obserwacjach i pamięci - swojej i innych. Co więcej, jego książkę można zaliczyć do przedsięwzięć pionierskich w tej dziedzinie badań, a w konsekwencji nie powinien dziwić ograniczony katalog odwołań. Co jednak istotne, książka była rodzajem podręcznika czy encyklopedii dla opinii publicznej. Podręczniki przedstawiaja zasoby wiedzy pewnej, zasadniczo niekwestionowanej w ramach pola, przedstawiającej fakty, a nie opinie czy hipotezy.

Reguły pola nauki zakładaja, że prace naukowe oceniane są przez osoby o zbliżonych kompetencjach i wiedzy (peer review). Autor encyklopedii, przeciwnie, dokonuje wykładu ex cathedra. Forma narracji Ustroju komunistycznego... jest niedyskursywna - ani nie ukazuje procesu dochodzenia do wiedzy w wyniku kształtowania się konsensusu, ani nie próbuje przekonać krytycznego czytelnika, lecz wykłada mu wiedzę pewną. W polu nauki badania systematyczne są epizodami w procesie poszukiwania naukowego konsensusu. Podręcznik czy encyklopedia wykłada wiedzę tam, gdzie ten konsensus został osiągnięty. Alasdair MacIntyre (2009: 57-58, 269 i nast.) wątpi, czy encyklopedyczna koncepcja wiedzy ma dzisiaj jeszcze w ogóle rację bytu. Stwierdza, że konsensus w humanistyce ma charakter jedynie lokalny, a nie dotyczy całości wiedzy. Systematyczna praca naukowa w sposób konieczny włącza autora w kontrowersję i proces kwestionowania konsensusu. Stosunek między opinią publiczną skupioną wokół podziemnego rynku wydawniczego a autorem miał charakter nienaruszalnego konsensusu odnośnie do moralnej oceny systemu komunistycznego.

Relacja między autorem podręcznika czy encyklopedii a czytelnikami jest hierarchiczna. Z jednej strony jest autorytet epistemiczny, dysponujący zasobem wiedzy, a z drugiej strony są ci, którzy mają tej wiedzy deficyt. Jest to relacja jednostronnego transferu wiedzy. Fakt, że książka przez pierwsze 
lata funkcjonowała pod pseudonimem, również powodował brak relacji zwrotnej - od czytelników do autora - nawet jeśli „w środowisku wszyscy wiedzieli, kto jest jej autorem" (Grabowska 2006: 347).

Bronią przeciw publicznemu dyskursowi ideologicznemu miał być wolny od wartościowań styl socjologii Karpińskiego. Styl był orężem w walce rządzonej regułami spoza pola nauki. Zamiast krytycznej dyskusji - swoistej dla pola nauki - w której książka jest jednym z epizodów, pojawiał się wykład ex cathedra. Funkcjonowanie książki w polu opinii publicznej opierało się na moralnym konsensusie między autorem i jego czytelnikami.

\section{/// Metoda semiotyki logicznej}

Metodologię Karpiński uprawiał jako dziedzinę badań filozoficznych. Tymczasem zaadoptowanie szeregu przekonań metanaukowych na gruncie nauk szczegółowych rodzi serię nowych problemów, które nie moga zostać rozwiązane na poziomie ogólnej refleksji epistemologicznej (Giddens 1974: 3). Rozstrzygnięcia metodologiczne stanowiły element kontekstu, w którym kształtowała się socjologia, lecz nie oferowały algorytmicznych zasad prowadzenia badań empirycznych. Stąd zasadniczym materiałem dla rekonstrukcji metody programu socjologii pozytywistycznej będa prace Karpińskiego z zakresu socjologii, a nie metodologii.

Karpiński przy opisie ustroju komunistycznego korzystał z warsztatu metodologicznego historii i socjologii. Posługiwał się obserwacją codziennego życia w PRL-u, analizą danych zastanych wytwarzanych przez administrację państwową, interpretacją artykułów w prasie oficjalnej, dokumentów urzędowych czy wypowiedzi przedstawicieli władzy. W państwach, gdzie aparat władzy w sposób systematyczny i na dużą skalę ogranicza dostęp do wiedzy o społeczeństwie oraz wytwarza narrację historyczna podporządkowaną oficjalnej ideologii, historycy współczesności znajduja się w wyjątkowo trudnej sytuacji. Karpiński, jak zauważa Antoni Dudek (2015: 166), „do perfekcji opanował umiejętność czytania między wierszami”. Dzięki temu tezy historyczne „pierwszego peerelisty” (Eisler 2015) znajduja potwierdzenie w systematycznych pracach dzisiejszych historyków mających dostęp do archiwów.

Socjologia wypracowała własne metodologie i twórczo zaadaptowała je $z$ innych dyscyplin (np. $z$ językoznawstwa czy antropologii), a poparcie tez w materiale empirycznym stanowi ważny element legalizacji różnych przedsięwzięć badawczych. Inaczej jednak niż w historii uprawomocnieniem dla prac socjologicznych jest zerwanie $z$ interpretacjami zdroworoz- 
sądkowymi i nadanie sensu dostępnym danym w języku teoretycznym. Środkiem do tego celu jest metoda.

Metodę należy odróżnić od metodologii rozumianej jako systematyczne i racjonalne stosowanie technik badawczych. Metodologia jest warunkiem koniecznym dobrej roboty socjologicznej, ale nie wystarczającym. Swobodnie mówiąc, metoda jest wobec metodologii nadrzędna. Metoda decyduje o refleksyjnym podejściu do zbierania danych, agregowania, opisywania i formułowania twierdzeń o przyczynach zjawisk. Metodę stanowią wszystkie zalegalizowane środki kognitywne, którymi posługuje się uczony do myślowego uchwycenia badanego przedmiotu. Metoda wyznacza ramy epistemiczne dla poznania dziedziny badań. Metodologia jest sposobem działania, metoda - myślenia. Stosuje metodę ten, kto w sposób uporządkowany, tj. zgodnie z jakąśs regułą, prowadzi swoje myśli.

Historycy pozytywizmu wśród jego cech dystynktywnych wymieniaja jedność metody wiedzy (Kołakowski 1966: 16-17). Jest to przekonanie, że sposoby osiagnięcia wiedzy pewnej w różnych naukach - i szerzej, różnych dziedzinach doświadczenia - są zasadniczo takie same. Karpiński odnalazł metodę w regułach formułowanych przez semiotykę logiczną ${ }^{7}$. Semiotyka logiczna z jednej strony ustala znaczenia takich terminów jak „definicja”, „wnioskowanie”, „uzasadnianie” czy „klasyfikacja”, a z drugiej strony formułuje zasady stosowania definicji, wnioskowań, uzasadnień i klasyfikacji w racjonalnym dyskursie. Racjonalność naukowa wymaga precyzyjnego, niemetaforycznego i pozbawionego perswazji opisu faktów. Przestrzeganie tego typu reguł jest jedną z cech nauki.

Autorzy tekstów naukowych klarują znaczenia pojęć, reguluja zakresy terminów, grupują elementy w klasy czy określają granice ważności wysuwanych tez. Definiowanie służy jednoznacznemu charakteryzowaniu przedmiotów, klasyfikowanie - ograniczeniu nieskończonej liczby indywiduów do kilku typów. Również socjologowie stosują te reguły w bardziej lub mniej systematyczny sposób: ze względu na pokrewieństwo języka nauk społecznych z językiem potocznym oraz różne rozumienie w ramach dyscypliny równokształtnych pojęć kluczowe staje się precyzowanie znaczeń używanych słów. Istnieje zgoda, że są to istotne procedury, które mają pomóc w realizacji zasadniczych strategii wyjaśniających. Zasad metody socjologicznej nie można jednak sprowadzić do logiki formalnej i reguł racjonalnego dyskursu.

\footnotetext{
7 Szczególne zasługi dla rozwoju semiotyki logicznej mieli nauczyciele Karpińskiego - Tadeusz Kotarbiński i Kazimierz Ajdukiewicz, autorzy podręczników do logiki i semiotyki (zob. m.in. Kotarbiński 1986, Ajdukiewicz 1975).
} 
Karpiński traktuje klasyfikowanie i definiowanie nie tylko jako element taktyki badawczej, ale również jako strategie wyjaśniająca (por. Love 2009: 57-58). Ze szczegółowych dyspozycji prowadzenia wywodu naukowego zostają one awansowane na poziom ogólnego planu badania naukowego. Metodologia staje się metoda rozumienia zjawisk: zasady formułowane przez semiotykę logiczną traktowane są jako metoda poznania socjologicznego. Edmund Mokrzycki (1990: 16) zauważał, że „w socjologii polskiej metodologia jest względnie autonomicznym systemem teoretycznym określającym naturę i przebieg procesu badawczego". To samo można powiedzieć również o socjologii Karpińskiego. Reguły racjonalnego dyskursu przeniesione zostały na poziom teorii socjologicznej. Semiotyka logiczna determinowała nie tylko formę dyskursu, ale również jego treść.

Klasyfikacje w Ustroju komunistycznym... są wszechobecne. Przedmioty definiuje się poprzez wskazanie rodzaju i różnicy. Różnica staje się własnością istotna, która dzieli rodzaj na gatunki. W ten sposób można wskazać własność lub listę własności, które są konieczne i wystarczające, aby orzec o czymś, że należy do danej klasy logicznej. Związek między różnymi elementami klasy opiera się na podobieństwie: posiadaniu tych samych cech istotnych. Stosując systematycznie metodę rodzaju i różnicy, przedmioty można klasyfikować hierarchicznie. Zrozumienie zjawiska polega na kwalifikacji rzeczy do odpowiedniego segmentu klasyfikacji.

\begin{tabular}{|c|c|c|}
\hline \multirow[t]{5}{*}{$\begin{array}{l}\text { systemy } \\
\text { partyjne }\end{array}$} & \multirow[t]{2}{*}{$\begin{array}{l}\text { systemy } \\
\text { współzawodnictwa }\end{array}$} & $\begin{array}{l}\text { systemy wielopartyjne (partie opozycyj- } \\
\text { ne są legalne, istnieje współzawodnictwo } \\
\text { o władzę, koalicje są możliwe) }\end{array}$ \\
\hline & & $\begin{array}{l}\text { systemy dwupartyjne (partie opozycyjne } \\
\text { są legalne, współzawodnictwo rzeczywiste, } \\
\text { koalicje nie są niezbędne do sprawowania } \\
\text { władzy) }\end{array}$ \\
\hline & \multirow{3}{*}{$\begin{array}{l}\text { systemy } \\
\text { monopolistyczne }\end{array}$} & systemy ściśle jednopartyjne \\
\hline & & $\begin{array}{l}\text { systemy z partią uprzywilejowaną (jedna } \\
\text { partia pełni funkcję kierowniczą, brak legal- } \\
\text { nych partii opozycyjnych) }\end{array}$ \\
\hline & & $\begin{array}{l}\text { systemy z partią dominującą (istnieją } \\
\text { partie opozycyjne, ale nie ma rzeczywistego } \\
\text { współzawodnictwa o władzę) }\end{array}$ \\
\hline
\end{tabular}

Tabela 3. Klasyfikacja systemów partyjnych zrekonstruowana na podstawie Ustroju komunistycznego w Polsce (Karpiński 2005: 36). 
Jeśli pytamy się o system partyjny w Polsce Ludowej (Tabela 3), to stwierdzamy, że jest to przykład systemu monopolistycznego z jedną partia uprzywilejowaną. Wprowadzenie serii rozróżnień pozwala dostrzec istotowe różnice między Polską a innymi państwami - demokratycznymi i niedemokratycznymi - ze względu na system partyjny.

Rozróżnienia w Ustroju komunistycznym... tylko niekiedy tworzą tego typu hierarchiczne klasyfikacje. Karpiński zazwyczaj posługuje się szeregiem podziałów logicznych, przeprowadzanych na podstawie różnych kryteriów. W taki sposób wprowadza np. pojęcie władzy i jej zakresu (zob. Tabela 4). W krótkim, trzystronicowym podrozdziale zatytułowanym Zakres władzy, Karpiński przedstawia serię klasyfikacji: dzieli władzę na pozytywną i negatywną oraz na władzę odnośnie do działań prostych i złożonych; zakres władzy z kolei można oceniać w trzech wymiarach: ze względu na możność jej sprawowania przez tego, kto władzę posiada, na jej treść i na podmioty, których dotyczy. Rozróżnienia stają się racją do przedstawienia lapidarnych tez dotyczących władzy i jej zakresu w Polsce Ludowej. Uchwycenie dziedziny badań dokonuje się w dwóch odrębnych etapach: wpierw jest to praca pojęciowa polegająca na konstrukcji klasyfikacji, a następnie decyzja, do której klasy należy zakwalifikować Polskę.

Przedmiot badań nie zawsze łatwo wpisuje się w zaprojektowane klasyfikacje. Alternatywą dla klas skonstruowanych według kryterium przyjętego a priori może być założenie podobieństwa rodzinnego. Oznaczałoby to, że można stworzyć listę własności, które działaja jako definicja klasy, choć rzadko zdarza się, aby wszystkie własności były charakterystyczne dla każdego jej elementu. Choć otrzymuje się konkretny opis klasy, to staje się jasne, że nie stanowi on żadnej istoty rzeczy.

Wyciagnięcie pełnej antyesencjonalistycznej konsekwencji z powyższego „antyidealizującego” rozumienia klas prowadziłoby do odrzucenia w ogóle kategorii podobieństwa. Klasy wówczas można rozumieć jako zbiory statystyczne, tworzone na podstawie współczynników korelacji cech w różnych wypadkach. Punktem wyjścia nie jest w takim podejściu definicja, która odkrywa istotę rzeczy. Procedura ma charakter indukcyjny: w wyniku badania korelacji zmiennych możemy pogrupować elementy w zbiory.

Karpiński przyjmuje jednak odmienna - aprioryczną, a nie indukcyjną - procedurę badawczą. Punktem wyjścia jest definicja pojęcia, które następnie stosuje się do dziedziny badań. Stoi za tym określony pogląd na znaczenie pojęć. Jeśli uznamy, że znaczenie pojęć jest ukonstytuowane przez definicję (czasem polega to na konstrukcji znaczenia w oderwaniu od 


\begin{tabular}{|c|c|c|c|c|c|}
\hline \multirow[t]{4}{*}{$\begin{array}{l}\text { I. RODZAJE } \\
\text { WŁADZY }\end{array}$} & \multirow[t]{2}{*}{ A } & $\begin{array}{l}\text { 1. pozy- } \\
\text { tywna }\end{array}$ & \multicolumn{3}{|c|}{$\begin{array}{l}\text { możliwość wprowadzania w życie decyzji } \\
\text { o określonej treści, dotyczących określo- } \\
\text { nych osób }\end{array}$} \\
\hline & & $\begin{array}{l}\text { 2. nega- } \\
\text { tywna }\end{array}$ & \multicolumn{3}{|c|}{$\begin{array}{l}\text { możność podejmowania i egzekwowania } \\
\text { „decyzji negatywnych”, to jest możność } \\
\text { zapobiegania czemuś lub zakazywania } \\
\text { czegoś }\end{array}$} \\
\hline & \multirow{2}{*}{$\begin{array}{l}\text { B. Złożo- } \\
\text { ność dzia- } \\
\text { łań, które } \\
\text { władza } \\
\text { obejmuje }\end{array}$} & $\begin{array}{l}\text { 1. decyzje } \\
\text { proste }\end{array}$ & \multicolumn{3}{|c|}{ działania proste } \\
\hline & & $\begin{array}{l}\text { 2. decyzje } \\
\text { złożone }\end{array}$ & \multicolumn{3}{|c|}{$\begin{array}{l}\text { długoterminowe i szeroko zakrojone } \\
\text { plany; } \\
\text { istotne sa wzajemne stosunki zamierzo- } \\
\text { nych działań i układ tych działań w cza- } \\
\text { sie (harmonizacja decyzji) }\end{array}$} \\
\hline \multirow[t]{5}{*}{$\begin{array}{l}\text { II. ZAKRES } \\
\text { WLADZY }\end{array}$} & \multicolumn{2}{|c|}{$\begin{array}{l}\text { 1. możliwości } \\
\text { (możliwość zrealizo- } \\
\text { wania decyzji, czyli } \\
\text { skuteczność) }\end{array}$} & \multicolumn{3}{|c|}{$\begin{array}{l}\text { kontinuum władza skuteczna - władza } \\
\text { nieskuteczna }\end{array}$} \\
\hline & \multirow{2}{*}{\multicolumn{2}{|c|}{$\begin{array}{l}\text { 2. czego dotyczy } \\
\text { (treść decyzji) }\end{array}$}} & polityczna & ekonomiczna & ideologiczna \\
\hline & & & \multicolumn{3}{|c|}{$\begin{array}{l}\text { np. życie organizacyjne, przemieszczanie } \\
\text { się w kraju i za granicę, środki informa- } \\
\text { cji, wychowanie, tworzenie i korzystanie } \\
\text { z dóbr kultury }\end{array}$} \\
\hline & \multicolumn{2}{|c|}{$\begin{array}{l}\text { 3. kogo dotyczy (zbiór } \\
\text { osób, do których } \\
\text { decyzje się odnoszą) }\end{array}$} & \multicolumn{3}{|c|}{ np. Kościół, wieś } \\
\hline & \multicolumn{2}{|c|}{$\begin{array}{l}\text { syntetyczna ocena } \\
\text { zakresu władzy obej- } \\
\text { mująca trzy powyższe } \\
\text { wymiary }\end{array}$} & $\begin{array}{l}\text { władza } \\
\text { ograni- } \\
\text { czona }\end{array}$ & $\begin{array}{l}\text { panowanie } \\
\text { (znaczny } \\
\text { zakres } \\
\text { władzy) }\end{array}$ & $\begin{array}{l}\text { władza } \\
\text { totalna }\end{array}$ \\
\hline
\end{tabular}

Tabela 4. Władza i zakres władzy na podstawie Ustroju komunistycznego w Polsce(Karpiński 2005: 49-51).

Karpiński, wprowadzając kolejne rozróżnienia analityczne, formułuje także wnioski empiryczne: 1. w Polsce Ludowej można mówić o władzy totalnej, która jednak nie zawsze była skuteczna i nie wszędzie sięgała; 2. aparat państwowy posiadał skuteczność odnośnie do decyzji prostych, nie posiadał władzy odnośnie do decyzji złożonych (brak umiejętności harmonizacji planów); 3. Kościół (ze strachu przed aktywną obroną przez wiernych) i wieś (przez własność prywatna) były wolne od totalnej władzy aparatu państwa; 4. aparat państwowy miał dużą władzę w polityce i gospodarce, w mniejszym stopniu obejmowało to obieg informacji i wychowanie. 
funkcjonujących sensów, lecz zazwyczaj na ich uregulowaniu), to podanie sensu terminu polega na wymienieniu cech koniecznych i wystarczających, które pozwalają orzekać o danym przedmiocie za pomocą danej nazwy. Znaczenie jest deskrypcja przedmiotu formułowaną w definicji.

Inaczej niż zwolennicy podobieństwa rodzinnego Karpiński za pomocą definicji ustala zamkniętą liczbę deskrypcji, które powinny charakteryzować każdy przedmiot, do którego odnosi się nazwa. Sprawa jest jednak bardziej złożona: stosujemy pojęcia również do tych zjawisk, które nie spełniają wszystkich cech wymienionych w definicji. W stylizacji epistemologicznej powiedzielibyśmy, że pojęcia są idealizacjami. Trudno w rzeczywistości o przedmioty, które spełniają wszystkie deskrypcje. Z punktu widzenia systemów realnych pojęcia nie mają empirycznych odpowiedników. Gdy jakiś element wpasowuje się w wyróżnione kategorie, to Karpiński nie modyfikuje znaczenia pojęcia, lecz rejestruje odstępstwa przedmiotu od pojęcia. W stylizacji ontologicznej można twierdzić, że przedmioty mocniej lub słabiej „uczestniczą w idei” bycia taką a taką rzeczą.

Grabowska z Szawielem (1978: 116) zauważają w swojej recenzji, że zestaw podstawowych pojęć używanych w książce przez Karpińskiego jest uniwersalny, „równie dobrze można by ich użyć do opisu liberalnych demokracji zachodnich". W konsekwencji, realny socjalizm jawi się jako odstępstwo od modelu. Autorzy recenzji domagają się stworzenia nowych pojecć dostosowanych do rzeczywistości: „Nowy ustrój wytworzył zjawiska jakościowo nowe, które domagają się właściwej im pojęciowości” (Grabowska, Szawiel 1978: 117).

Sprawę dodatkowo komplikuje fakt, że pojęcia, o których mówi Karpiński, mają charakter złożony i stopniowalny. Na pojęcie zakresu władzy składa się zarówno to, jakie możliwości realizacji swoich decyzji ma ten, kto władzę dzierży, jak i to, czego ona dotyczy i jakie podmioty obejmuje. Można powiedzieć, że są to trzy różne rozumienia terminu ,zakres władzy", które można analizować osobno. Co więcej, w każdym z tych wymiarów zakres władzy może być większy lub mniejszy: pojęcia można opisać za pomocą zmiennych ciąłych. Władza może być bardziej lub mniej totalna, a nie tylko totalna i nietotalna. Ze względu na ,nasycenie” przedmiotu daną własnością możemy stwierdzić ostatecznie, czy posiada on daną cechę, czy nie. Decyzja dla samego Karpińskiego opiera się na ilustracjach i zdrowym rozsąadku.

Ze względu na aprioryczna procedurę definiowania Karpińskiego można za Karlem Popperem (1999: 38) nazwać „esencjalistą metodologicznym": 
Esencjaliści metodologiczni skłonni są formułować problemy naukowe w postaci pytań: „czym jest materia?”, „czym jest siła?”, „co to jest sprawiedliwość?” itp. Wierzą zarazem, że niezbędnym warunkiem, a może nawet głównym celem nauki jest udzielanie na te pytania wyczerpujących odpowiedzi, które ujawnią istotę tych pojęć, a zatem odsłonią prawdziwą naturę określanych przez nie istot.

Stawianie problemów w Ustrój komunistyczny... przyjmuje opisaną przez Poppera formę: w powyższym przykładzie autor wpierw stara się wyjaśnić, czym w istocie rzeczy jest władza totalna (temu służą rozważania o zakresie władzy), a potem orzeka, że o Polsce Ludowej - zachowując poprawkę idealizacyjna - można mówić jako o państwie rządzonym przez władza totalną. Orzekanie o ówczesnym ustroju odbywa się na podstawie celnych, lecz mocno rozproszonych obserwacji codziennych, a nie systematycznie konstruowanych danych.

Popper (1999: 38) przekonuje, że w naukach przyrodniczych przeważającym poglądem jest nominalizm metodologiczny, który traktuje słowa jedynie jako użyteczne narzędzia opisu. Nominalista pyta nie o materię w ogóle, tylko o ten konkretny kawałek materii. Karpiński robi inaczej - wpierw pyta o zjawiska in abstracto, a potem szuka ich w rzeczywistości komunistycznej Polski. Przyjęta metoda sprawia, że nie jest jasne, do czego faktycznie pojęcia się odnoszą: są obdarzone znaczeniem, ale nie posiadają przezroczystości semantycznej. Nasza uwaga nakierowana jest na słowa (klasyfikacje i definicje), a nie na przedmioty, do których mają się odnosić.

Przytaczane przez Karpińskiego definicje nie maja wyłącznie charakteru wyjściowego dla dalszych rozważań, lecz stanowią cel sam w sobie. Karpiński odrzuca stanowisko odnośnie do znaczenia nazw, zgodnie z którym wszystkie użycia nazwy „nasączaja” je sensem. Przytaczane przez Karpińskiego definicje mają niejako charakter rozstrzygający: opierają się na pracy logicznej, a nie empirycznej. Formalnie prawidłowo skonstruowana definicja nigdy nie będzie fałszywa, a w konsekwencji nie jest podatna na modyfikacje. Można oczywiście zawsze wyróżnić jakieś kolejne wymiary analityczne (wówczas należałoby mówić o władzy , władzy $_{2}, \ldots$, władzy $_{n}$ ), ale Karpiński nie stawia pytań o ich wzajemne odniesienie i próby konstrukcji pojęcia uogólnionego. Analityczne rozróżnienia nie zawsze są adekwatne empirycznie. Rozstrzygnięcia powinny być dokonywane nie na drodze spekulacji, lecz konfrontacji z empirią. 
Budowany przeze mnie argument nie ma na celu stwierdzenia, że Karpiński budował definicje w oderwaniu od empirii. Miał przecież szeroką wiedzę na temat ówczesnego systemu, opartą chociażby na własnej działalności opozycyjnej. Chodzi raczej o to, że traktował definicję jako punkt dojścia swoich dociekań, a nie wyjścia do dalszych badań. Krytyka metody Karpińskiego nie jest przeprowadzana również z pozycji „,naiwnego realizmu”: jest oczywiste, że obserwacja jest zawsze uteoretyzowana i nie można prowadzić badań empirycznych w oderwaniu od rozważań pojęciowych. Zarazem jednak staje się jasne, że przyjęta przez Karpińskiego metoda posiadała daleko idące ograniczenia dla empirycznych badań rzeczywistości społecznej.

Karpiński przyją, że formułowanie definicji i konstruowanie klasyfikacji są wymiarem konstytutywnym dla myślenia naukowego. $\mathrm{Z}$ pewnością miało to znaczenie w ówczesnym kontekście społecznym, gdzie partyjni ideolodzy posługiwali się pojęciami nieostrymi o chwiejnych sensach, w argumentacjach korzystając z polisemii wyrazów. Strategia, która sprawdzała się w dyskursie publicznym, okazała się antyskuteczna w nauce. Po pierwsze, definicja jest w nauce punktem wyjścia dla określenia sensu pojęć, które nasączane są właściwym znaczeniem wraz z kolejnymi użyciami. Po drugie, przyjmując, że celem kognitywnym Karpińskiego był opis ustroju komunistycznego rozumianego jako pewien przedmiot historyczny o określonych współrzędnych czasowo-przestrzennych (a nie przedmiotu z zakresu zjawisk abstrakcyjnych, co też jest zalegalizowanym w socjologii podejściem), przyjęcie podejścia esencjalisty metodologicznego było chybione jako strategii do realizacji tego celu. Karpiński traktował przypadek Polski jako egzemplifikację (z poprawką idealizacyjna) definiowanych przez niego pojęć. Tymczasem pojęcia używane do opisu rzeczywistości o określonych współrzędnych czasoprzestrzennych nie powinny być konstruowane w oderwaniu od rzeczywistości historycznej. Karpiński był metodologiem, który budował definicje i klasyfikacje ze swoboda i finezją. Była to dla niego jednak praca myślowa, a nie praca opierająca się na systematycznych badaniach empirycznych. W konsekwencji nie było możliwe, aby referencje pojęć przebiegały w poprzek przyjętych na początku definicji. Podobnie proces klasyfikowania przypadków nie ma charakteru biernego, lecz jest procesem modyfikowania przyjętych na początku badania znaczeń i zasad podziału. Polski system komunistyczny powinien być nie tylko ilustracją tez ogólnych, lecz także samym przedmiotem badań. 


\section{/// Ontologia kompleksu}

Ontologię społeczną można badać na dwa zasadniczo różne sposoby: transcendentalny i analityczny. W perspektywie transcendentalnej filozofowie za pomoca aparatury pojęciowej charakterystycznej dla własnej dyscypliny (m.in. ontologicznej, logicznej, z zakresu filozofii języka, filozofii umysłu czy filozofii działania) formułują tezy dotyczące tego, co istnieje, w jaki sposób oraz jakie ma własności w dziedzinie społecznej. Pytają oni również o związki między faktami społecznymi a faktami psychicznymi czy fizycznymi. Abstrahuja przy tym od prac empirycznych z zakresu nauk społecznych. Jeśli do nich sięgaja, to w poszukiwaniu ilustracji, a nie analizy zawartych tam pojęć. Taki sposób refleksji jest autonomiczny wobec nauk społecznych: może z nich czerpać przykłady, lecz nie odnosi się w sposób szczególny do partykularnych empirycznych systemów pojęciowych socjologów, ekonomistów czy antropologów. Punktem wyjścia dla podejścia analitycznego jest sposób problematyzowania zjawisk w empirycznych badaniach rzeczywistości społecznej, a refleksja filozoficzna służy wyklarowaniu używanych terminów i ukazaniu niejawnych przesłanek. O ile prace z zakresu transcendentalnej ontologii społecznej mówią o zagadnieniach metafizycznych wprost, o tyle prace empiryczne posiadaja przede wszystkim wektor epistemologiczny. Badacze społeczni muszą odpowiadać sobie na pytania, jakie twierdzenia są uzasadnione, jakie dane ugruntowują głoszone tezy, jak zwiększyć stopień ich konfirmacji itp. Rekonstrukcje ontologiczne mają siłą rzeczy charakter wtórny. O ile perspektywa transcendentalna stawia sobie za zadanie odkrycie ostatecznych i najogólniejszych fundamentów ontycznych oraz „głębokiej” struktury rzeczywistości, o tyle perspektywa analityczna szuka podstawowych kategorii i relacji między nimi na gruncie języka teorii naukowej. Uchylam się od odpowiedzi na pytanie o relację między tymi dwoma podejściami, ponieważ sięgają one do kluczowych problemów metafizyki: relacji między, z jednej strony, doświadczeniem zmysłowym, intuicją czy pojęciami językowymi a światem z drugiej. Konstatuję jednak obecność tych dwóch perspektyw w dyskursie metodologicznym.

Karpiński prowadził refleksję ontologiczną w orientacji transcendentalnej na temat pojęcia kultury i struktury społecznej, prawa (Karpiński 1992) i zbiorowości (Karpiński 1985). Formułował również ogólne tezy dotyczące sposobów istnienia przedmiotu badań socjologii (Karpiński 2006). Punktem wyjścia dla tych rozważań były m.in. pluralistyczne koncepcje Romana Ingardena, Leona Chwistka czy Karla Poppera, reizm Tadeusza Kotarbińskiego, mereologia Stanisława Leśniewskiego, teoria całości Mariana Borowskiego. 
Ustrój komunistyczny... posiada teoretyczne przesłanki korespondujące ze stanowiskiem ontologicznym zajmowanym przez Karpińskiego.

Karpiński widział układy społeczne jako twory heterogeniczne: w ich skład wchodzić miały byty różnych kategorii, o różnym statusie ontologicznym. Jądro układów społecznych stanowią zbiorowości złożone z ludzi. Relacja między jednostkami a zbiorowościami to relacja mereologiczna, tj. relacja między nieprzypadkowo wyodrębnionymi częściami a całością (Karpiński 1985: 110). Ponadto, w skład układów społecznych można włączyć ,wytwory człowieka i inne przedmioty z owymi zbiorowościami związane" (tamże: 119). Za Władysławem Tatarkiewiczem Karpiński (1992: 12) włączał w zakres bytu, jakim jest cywilizacja, rzeczy o bardzo różnym statusie ontycznym: „rzeczy, dodane przez człowieka lub przetworzone, czynności, organizacje, a także ideologie, które przyczyniły się do powstania rzeczy, czynności i organizacji”"

W Ustroju komunistycznym... uwaga Karpińskiego skierowana była na dwie zasadnicze zbiorowości: rządzących i rządzonych, czyli władzę i społeczeństwo. Na rządzących składają się takie zbiorowości, jak elita władzy, administracja państwowa, partia uprzywilejowana, aparat policji politycznej, przemysł, wojsko, nomenklatura, aparatczycy. Również społeczeństwo można dzielić na mniejsze zbiorowości: miasto, wieś, grupy zawodowe, Kościól, Solidarność. Znacznie więcej miejsca Karpiński poświęcił rządzącym niż rządzonym: wiązało się to z przekonaniem o dominującym charakterze tego układu. Układ władzy i układ rządzonych posiadały swoje korelaty, odpowiednio: ideologię komunistyczną i katolicyzm, środki oddziaływania informacyjnego (oświata, środki masowego przekazu) i prasę podziemna, środki produkcji i siłę roboczą. Specyficznymi cechami komunistycznego układu społecznego były m.in. etatyzm, monopartyjność, monolityzm, centralizm, totalizm.

Umberto Eco (2007: 144) radził młodym badaczom, żeby pisanie pracy dyplomowej zaczynali od wymyślenia tytułu, gdyż: ,już dobry tytuł jest pewnym projektem". Podobnie jest z książką akademicką: tytuł koncentruje naszą uwage na temacie badania i aspekcie, w jakim problem jest analizowany. Ciekawa wydaje się zmiana, która zaszła między drugim i trzecim wydaniem książki Karpińskiego: intrygujący tocqueville’owski tytuł Nowy ustrój $i$ ewolucja został zastąpiony encyklopedycznie brzmiącym Ustrój komunistyczny w Polsce. Dwukrotna modyfikacja w tytule dzieła Alexisa de Tocqueville’a sugerowała myślenie wychodzące od problemu: każe pytać o ewolucję systemu społecznego powstałego w Polsce po II wojnie światowej. To jednak drugi tytuł lepiej odzwierciedla zawartość książki. 
W Ustroju komunistycznym... Karpiński swoją uwagę badawczą koncentruje nie na problemie, lecz na przedmiocie: tytułowym ustroju komunistycznym. Narracja książki jest skonstruowana według wektora ontologicznego, a nie epistemicznego.

W Taternictwie nizinnym Karpiński (1988: 122-123), rekonstruując motywy powstania książki, stwierdzał, że socjologia w latach 70 . badała jedynie powierzchnie zjawisk, ponieważ przyjęła ankietę jako uprzywilejowany sposób poznania rzeczywistości. W konsekwencji zamiast badać Polskę, socjologowie poznawali jedynie Polaków. Wyjaśnia, że sam chciał wiedzieć, „jak społeczeństwo jest zorganizowane, jak postępuja władze i jaki napotykają opór, zwłaszcza w okresie prawdy, w momentach przełomu, w których zmieniają się przekonania ludzi na temat możliwości działania i poza rządzącymi dochodzą do głosu inne osoby i inne zbiorowości, odzywają się nieoficjalnie i przedtem nieuznawane podmioty zmian społecznych". Konsekwentnie stosowana metoda klasyfikacji i definiowania zapewnia co prawda oryginalność całemu przedsięwzięciu i wyjście poza zdroworozsądkowy opis zjawisk, ale nie jest dla czytelnika jasne, jaki jest cel epistemiczny książki. Z pewnością nie jest nim opis i wyjaśnienie ewolucji systemu komunistycznego - jak sugerował pierwszy tytuł - bo koncepcja zmiany jest zaledwie naszkicowana (zob. uwagi nt. trudności teoretycznych przy budowie modelu zmiany, [w:] Karpiński 2005: 263-265, por. Kula 2005: 16). Nie tyle chodzi jednak o brak koncepcji zmiany, ile jakiegokolwiek jasno postawionego problemu. W konsekwencji książka ma strukturę amorficzną: składa się z części, które nie pozostają między sobą w jasnych związkach. Deficyt spójności narracji ma swoje źródła w przyjętej ontologii zjawisk społecznych. Podział książki na liczne i krótkie podrozdziały sprawia, że czytelnik konfrontowany jest z opisami przedmiotów, ale z trudem może dojrzeć całość, która ma się wyłonić z ich sumy. Przedmioty nie sa przedstawione „w ruchu”, „w działaniu” (nawet jeśli miałoby to być działanie nakierowane na utrwalanie status quo). Brak jest „praw ruchu formacji komunistycznej”, praw jej „ewolucji”.

Twórcy XX-wiecznego nurtu filozofii analitycznej - Gottlob Frege, Bertrand Russell i Ludwig Wittgenstein - posługiwali się rozróżnieniem na fakty i kompleksy. Warto przywołać tę dystynkcję, gdyż pomoże zrozumieć błąd Karpińskiego: posługiwanie się „ontologią kompleksu” w celu uchwycenia całości systemu spotkało się z niemożliwym do przekroczenia ograniczeniem ${ }^{8}$.

${ }_{8}^{8}$ Poniższa rekonstrukcja rozróżniania na kompleksy i fakty opiera się na rozdziale Complex and fact z książki Michaela Pottera Wittgenstein's Notes on Logic (2011). Zaadoptowanie dystynkcji jest przykła- 
Dobrze istotę rozróżnienia obrazuje cytat z rozprawy Fregego Myśl studium logiczne:

Prawda nie jest własnością, która byłaby związana z jakąś kategorią wrażeń zmysłowych. Odróżnia ją to ostro od takich własności jak te, które odpowiadają wyrazom „czerwony”, „gorzki” czy „pachnący”. A czy nie widzimy, że Słońce wzeszło? I czy nie widzimy tym samym, że jest to prawda? To, że Słońce wzeszło, nie jest przedmiotem, który wysyła docierające do mego oka promienie; nie jest to żadna rzecz widzialna, jak samo Słońce. Prawdziwość tego, że Słońce wzeszło, poznajemy na podstawie wrażeń zmysłowych. Mimo to prawdziwość nie jest własnością postrzegalną zmysłowo (2014: 105-106).

Gdy zamiast Fregowskiej „prawdy” podstawi się w powyższym wyimku słowo „fakt”, to istota rozróżnienia staje się jasna. Nie wystarczy zestawić szeregu przedmiotów (własności, wrażeń), aby stwierdzić, że jakiś fakt miał miejsce. To, że Słońce wzeszło, nie jest równoważne wrażeniom, które o tym świadczą. Kompleks elementów jest nośnikiem faktów.

Kompleks jest układem obiektów, przedmiotów, rzeczy, części czy wrażeń. Dla Wittgensteina kompleksy w przeciwieństwie do faktów nie są dostępne w doświadczeniu. Zauważał on: „powiedzenie, że czerwone koło jest złożone z czerwoności i owalności albo że jest kompleksem z takich składników-części, jest nieprawidłowym użyciem tych słów i wprowadza w błąd" (cyt. za Potter 2008: 103-104, Wittgenstein 1974: 200). Kompleksy są nieme i niemożliwe do pomyślenia. Potter stwierdza, że do kompleksów możemy odnieść się przez deskrypcje, czyli wymieniając elementy, które wchodzą w jego skład. Tymczasem fakty poznajemy przez zdania. W doświadczeniu nie ,sumujemy” prostych przedmiotów w kompleksy, ale pojmujemy fakty, czyli to, że przedmioty są ułożone w taki, a nie inny sposób. Kompleks może być nośnikiem różnych faktów, lecz odwrotna relacja nie zachodzi. Kompleks jako taki nie faworyzuje jakiegokolwiek faktu.

dem transferu pojęcia w inny zakres problemowy, a w konsekwencji nasycone zostaje ono nowym sensem. Rozróżnienie zastosowane do książki Karpińskiego przyjmuje inne znaczenie niż w kontekście pierwotnym. Badania ontologiczne prowadzone przez Fregego, Wittgensteina i Russella były nierozerwalnie sprzęgnięte z badaniami języka: strukturę świata można było poznać poprzez badanie nazw i zdań (musiało to być poprzedzane analiza, która pozwalała wydobyć ze zdań potocznych sądy logiczne). Zastosowanie do pracy Karpińskiego rozróżnienia na „kompleks” i „fakt” wymaga transpozycji tych pojecć: przejścia z poziomu nazw i zdań na poziom struktury narracyjnej całej książki: podziału na rozdziały i podrozdziały, które mają odpowiadać elementom przedmiotu, jakim jest ustrój komunistyczny. 
Przenosząc powyższe rozumowanie z poziomu deskrypcji i zdań na poziom narracji, należy stwierdzić, że budowa książki Karpińskiego ma formę encyklopedii: hasła opisuja przedmioty w świecie, ale brak jest tez na jego temat. Amorficzność książki nie oznacza braku porząalku w ekspozycji materiału; podobnie jak encyklopedia posiada uporządkowane hasła, tak Ustrój komunistyczny... posiada czytelną strukturę. Otrzymujemy jednak deskrypcję przedmiotów, które mają nam przekazać wiedzę o kompleksie. Faktycznie, nie mamy do niego poznawczego dostępu tak długo, jak długo nie wypowiemy zdań o faktach, których kompleks jest substratem. Karpiński nie widzi ontologicznej różnicy między kompleksami a faktami. Sądzi, że przekazanie opisu elementów daje nam wiedzę o całym złożonym przedmiocie. Z opisu części nie przybywa nam wiedzy o tym, co dzieje się z całością. Ustrój komunistyczny jest przedmiotem wirtualnym: obiecanym w tytule, lecz nie zmaterializowanym w narracji. Koncentracja na analizie złożonego przedmiotu (kompleksu), a nie faktu sprawia, że Ustrój komunistyczny... może być źródłem inspirujących hipotez na temat elementów systemu komunistycznego, ale nie zawiera jego teorii.

Karpiński dystansował się wobec socjologii traktującej ludzi jako jedyne jednostki analizy. Za takim poglądem przemawiały pluralistyczne ontologie Chwistka, Ingardena czy Poppera. Formulował bogatą ontologię dla przedmiotów wyższego rzędu: struktur, prawa, cywilizacji, zbiorowości. Nie znajdowało to jednak przełożenia na bogaty teoretycznie program badawczy. Choć akceptował istnienie innych przedmiotów niż jednostki ludzkie, to niewiele mówił, w jaki sposób te przedmioty istnieją, zwłaszcza zaś, w jaki sposób istnieje system komunistyczny. Tymczasem od logiki kompleksu należałoby raczej skłonić się do logiki faktu. Świat, również świat społeczny, jest ogółem faktów, nie rzeczy (por. Wittgenstein 2004: 5 , teza 1.1). Ich opis nie polega na deskrypcji przedmiotów, które wchodzą w skład świata, ale na powiedzeniu, w jaki sposób istnieje przedmiot wyższego rzędu, jakie relacje i oddziaływania łączą jego elementy. W konstrukcji narracyjnej książki powinno znajdować to wyraz w łatwo dającej się zidentyfikować problematyce.

\section{/// Pozytywistyczny program Karpińskiego}

Nurt socjologii pozytywistycznej jak każdy duży paradygmat jest wewnętrznie zróżnicowany. Jeśli przyjrzymy się jego charakterystykom - zarówno konstruowanym dla partykularnych formacji intelektualnych, jak 
i starających się opisać nurt abstrakcyjnie jako przejaw powtarzającej się w historii idei - to dostrzegamy wspólny katalog cech.

Robert C. Bannister (1987: 3), podsumowując tradycję „obiektywizmu amerykańskiego" - nurtu z końca XIX i pierwszej połowy XX wieku - wymienia postulaty: obserwacji zachowania jednostek, rygorystycznej metody naukowej oraz neutralności w zakresie etyki i polityki. John Madge (1964: 1-3), autor zestawienia wzorcowych dzieł socjologii naukowej, dojrzałość socjologii widzi w posiadaniu zaawansowanych metod zbierania danych, ich analizy oraz wyrafinowanych narzędzi konceptualnych. Śladem nauk przyrodniczych badacze powinni formułować i testować sensowne hipotezy. Posiadanie dobrej teorii powinno również, zauważa Madge, przekładać się na możliwość kształtowania rzeczywistości społecznej. Anthony Giddens (1974: 3-4) we wstępie do wyboru tekstów krytykujących przejawy „postawy pozytywistycznej” stwierdza, że do jej założeń należą przekonania: o możliwości bezpośredniego zaadaptowania metodologii nauk przyrodniczych na gruncie socjologii, o paralelności terminów, w których przedstawia się rezultaty badań w naukach przyrodniczych i socjologii, oraz o instrumentalnym charakterze wiedzy naukowej, która nie ma żadnych logicznych implikacji dla polityki. Z kolei Peter Halfpenny (2005) w Encyclopedia of Social Theory przyjmuje strategie prezentacji pozytywizmu oczami krytyków. Często dopiero kontestując idee, dostrzegamy podobieństwo u heterogenicznych, prima facie, badaczy czy myślicieli. Ci, którzy dotychczas pozostawali w permanentnym sporze, zostaja uznani za przedstawicieli tego samego paradygmatu. Halfpenny krótko referuje zarzuty wobec: ideału nauki wolnej od wartościowań (pozytywizm, stawiając za cel nauki techniczną kontrolę, jest narzędziem opresji stosowanym przez klasę dominująca); empiryzmu opierającego się na bezpośrednim doświadczeniu bez odkrywania ukrytych przyczyn leżących u podstaw zjawisk dostępnych w doświadczeniu; postulatu jedności nauki (nauki społeczne, które - na wzór nauk przyrodniczych - badają relacje kauzalne, pomijaja ,,znaczenia” działań podejmowanych przez aktorów społecznych); obiektywnych standardów, które pozwalają badać świat taki, jaki jest (faktycznie nasze reprezentacje świata społecznego i naturalnego maja charakter konstrukcji).

Zasadnie można pytać, które z powyższych charakterystyk stworzone przez różnych badaczy spełnione zostają w pracach Karpińskiego. Istnieje jednak istotna wada takiego podejścia. Dychotomiczne klasyfikacje konstruowane są na wysokim poziomie ogólności. Łącza pod jedną etykietą zróżnicowane wartości kognitywne, angażują wielkie przeciwstawienia epistemologiczne, z których każde łączy zagmatwany bagaż znaczeń: wy- 
jaśnianie versus rozumienie, modelowanie versus narracja, metody ilościowe versus jakościowe, teoria versus deskrypcja, holizm versus indywidualizm, socjologia wolna od wartościowań versus socjologia krytyczna itd. (Berthelot 2001a: 465-466). Kwalifikacja socjologii Karpińskiego do członów powyższych opozycji nie pozwoliłaby odkryć jego naukowego idiolektu. Dlatego powyżej zastosowana została odmienna strategia: socjologia Karpińskiego była przedstawiona $\mathrm{w}$ trzech aspektach - retoryki, metody i ontologii z których wydobyte zostały punkty konstytutywne dla jego pozytywistycznego programu socjologii empirycznej. W trzech punktach podsumować należy to następująco:

1. Książka Karpińskiego Ustrój komunistyczny w Polsce ze względu na kontekst polityczny funkcjonowała w polu opinii publicznej, a nie w polu nauki. Przez wiele lat logiczni pozytywiści czy Karl Popper w centrum swoich zainteresowań stawiali problematykę demarkacji nauki od innych dziedzin życia. Ponieważ jednak nauka jako społeczna instytucja była poza horyzontem ich poznawczych zainteresowań, to skupiali się oni na wskazaniu formalnych reguł dyskursu, które wyznaczały zdania języka nauki. W przekonaniu Karpińskiego wolność słowa miała znaczenie kluczowe dla funkcjonowania nauki, ale przestrzeganie reguł racjonalnego dyskursu miało rekompensować braki instytucjonalne. Kontekst polityczno-wydawniczy miał jednak daleko idące konsekwencje: determinował zarówno obiorcę, a pośrednio i treść książki, jak i jej dalsze losy.

Karpiński (2000: 171-173) podobnie jak Halfpenny referował w Encyklopedii socjologii stanowiska krytyków socjologicznego pozytywizmu. Odrzucali oni w praktyce badawczej monopol metod ilościowych, indukcjonizm, niechęć do teoretyzowania, oszczędność pojęciowa, wolność od wartościowań, „empirycyzm”, ostrożność poznawczą oraz naturalizm. Karpiński (2000: 173) zaleca ostrożność i wskazuje, że „,antypozytywiści odnoszą nad pozytywistami łatwe zwycięstwa, gdy osądzają pozytywizm na podstawie skrajnych, niewstrzemięźliwych wypowiedzi pozytywistów". Sam szukał cechy dystynktywnej w oszczędności i ścisłości wypowiedzi oraz doświadczalnej kontroli wniosków. W ostatnim zdaniu swojego artykułu przytaczał fragment Etyki nikomachejskiej mówiący, że o ścisłość należy dbać w tej mierze, w jakiej pozwala na to natura badanego przedmiotu. Jest to skromna definicja, pod którą - przy różnym rozumieniu tego postulatu - podpisałaby się pewnie większość badaczy. Konkretyzację tej zasady widział w regułach formułowanych przez semiotykę logiczną. W ramach przyjętej perspektywy w badaniach nad nauką Karpiński nie problematyzował społecznych kryteriów naukowości. Nie znaczy to, że nie 
był wrażliwy na problematykę wolności słowa i nie zdawał sobie sprawy, że ma ona wymiar konstytutywny dla funkcjonowania instytucji naukowych. Z pewnością jednak większą wagę przywiązywał do własności samego tekstu niż do sytuacji społecznej, w jakiej dzieło funkcjonowało. W polu nauki tekst ma służyć przedstawieniu dowodu na rzecz wysuwanych tez oraz być poddawany ciągłej krytyce przez równe sobie racjonalne podmioty. Normy pola opinii publicznej wymagaja, żeby tekst wyrażał podzielany przez grupę system wartości i aby przyjęła ona wykład ex cathedra głoszony przez autorytet epistemiczny. Nie był to jednak wybór Karpińskiego, a konsekwencja kontekstu wydawniczego zdeterminowanego przez czynniki polityczne.

2. Nie społeczne funkcjonowanie ma jednak decydować według pozytywistów o naukowości wywodu. Za Hansem Reichenbachem można powiedzieć, że kontekst uzasadnienia jest niezależny od kontekstu odkrycia i kontekstu krytycznego. Gwarantem konstytuującym kontekst uzasadnienia jest dla Karpińskiego metoda - semiotyka logiczna wyposażona w normy prawidłowej konstrukcji definicji i klasyfikacji. Żywił on przekonanie, że stosowanie reguł racjonalnego dyskursu opierającego się na jasnym i precyzyjnym języku zapewni legalność całemu przedsięwzięciu. Specyficzna wizja znaczenia pojęć naukowych (znaczenie to deskrypcja podana w definicji) prowadziła do esencjalizmu metodologicznego. Celem naczelnym stało się analityczne wyróżnianie wymiarów pojęć i opierało się na pracy apriorycznej bez konfrontacji z badanymi przedmiotami. Opis partykularnych przedmiotów był relacją egzemplifikacji pojęć przez casus Polski okresu PRL-u. Stąd konieczność podkreślania idealizacyjnego charakteru pojecć, zaznaczania, że cechy mają charakter stopniowalny, a przedstawione modele mają charakter typów idealnych.

3. Wreszcie, wbrew zamierzeniu, Karpiński nie opisał ustroju komunistycznego. Przyjęcie ontologii kompleksu sprawiło, że opisywał poszczególne elementy systemu społecznego, nie formułując jednak na poziomie narracji żadnego problemu odnośnie do całego systemu. Stosowana w książce ontologia nie pozwoliła mu na uchwycenie przedmiotu. Dostęp mamy jedynie do faktów, czyli sposobu bycia kompleksów. W konsekwencji czytelnicy otrzymali dzieło o amorficznej narracji.

Relacja między wymiarem retorycznym metody i ontologii nie jest relacja wynikania logicznego. Zwraca jednak uwagę fakt, że encyklopedyzm, klasyfikacjonizm i ontologia kompleksu wzajemnie się ugruntowuja. Odrzucenie społecznych norm dochodzenia do konsensusu naukowego, 
przy zachowaniu kryterium demarkacji nauki od innych sfer, wymagało metody legalizującej całe przedsięwzięcie. Karpiński znalazł ją w semiotyce logicznej. Definicje i klasyfikacje stały się nie tylko formalnym narzędziem z poziomu taktyki badania, ale urosły do poziomu strategii, determinującej semantykę teorii. Koncentracja na definiowaniu prowadziła do przyjęcia postawy esencjalisty metodologicznego, który koncentruje się na odkryciu sensów pojęć, a nie odkrywaniu i modelowaniu za pomoca środków językowych rzeczywistości empirycznej. Powstała luka między pojęciami a rzeczywistością, którą Karpiński wyjaśniał idealizacyjnym charakterem pojęć. Przyjęta teoria znaczenia pozostawała również w związku z przyjętą ontologia kompleksu: prowadziła do przekonania, że podanie deskrypcji przedmiotu zapewnia przezroczystość semantyczną i pozwala ustalić referencję. W rzeczywistości można się odnieść tylko do faktów, których kompleksy są nośnikami. Karpiński przedstawia fakty na temat elementów ustroju komunistycznego, ale nie na temat jego samego. W konsekwencji narracja całej książki staje się pozbawiona wątku przewodniego.

Konstytucja programu miała spójne podstawy, zarazem jednak każdy wymiar okazywał swój deficyt. Program ze względu na zawarte u swoich podstaw zasadnicze wady nigdy nie stał się programem „postępowym” w sensie Lakatosa, nie stał się podstawą do kolejnych teorii, które modyfikowałyby pierwotne jej sformułowanie?. Podstawy programu (twardy rdzeń) okazały się nakładać zbyt daleko idące ograniczenia.

Należy tu zastrzec jedną ważna rzecz. Mówiąc, że program Karpińskiego nie był kontynuowany, nie twierdzę, że system komunistyczny nie stał się nigdy więcej przedmiotem naukowej refleksji socjologów. Wręcz przeciwnie, Karpiński okazał się uczonym awangardowym w studiach nad realnym socjalizmem, pisał swoją książkę, gdy badań nad „zmierzchem formacji”" jeszcze nie było. Jego przedsięwzięcie miało charakter pionierski: zarówno jeśli chodzi o przedmiot badania, jak i sposób teoretyzowania. W latach późniejszych, gdy wraz z wybuchem Solidarności trwanie systemu przestało być rzeczą samooczywistą, pojawiły się prace analizujące system społeczny i polskie społeczeństwo jako całość. Teoretyzowanie na temat polskiego ustroju i społeczeństwa socjalistycznego prowadzone było w ramach innych programów badawczych posiadających odmienne epistemologie. Konfrontacja dzieła Karpińskiego z pracami Stefana Nowaka

\footnotetext{
${ }^{9}$ Zgodnie z wizją Lakatosa (1995) programy badawcze są seriami teorii. Program składa się z twardego jądra i pasa ochronnego. Każda kolejna teoria powstaje poprzez modyfikację pasa ochronnego teorii, czyli tych jej cech, które zgodnie z heurystyką pozytywną mogą być zmieniane.
} 
i Władysława Adamskiego, Jadwigi Staniszkis i Winicjusza Narojka, Leszka Nowaka czy Adama Podgóreckiego oraz rozpoznanie w nich inspirujących elementów daleko przekracza cele tego artykułu. Niech niniejszy tekst stanie się przyczynkiem do dalszych opracowań.

Epistemologia socjologii, którą zrekonstruowałem na podstawie Ustroju komunistycznego..., nie generowała płodnych heurystyk badawczych. Spotkanie z rzeczywistością empiryczną okazało się dla Jakuba Karpińskiego trudniejszym wyzwaniem niż badanie idei.

Bibliografia:

/// Ajdukiewicz K. 1960. Naukowa perspektywa śmiata, [w:] tegoż, Jezyk i poznanie, t. 1, Wybórpism z lat 1920-1939, PWN.

/// Ajdukiewicz K. 1975. Logika pragmatyczna, PWN.

/// Bannister R. 1987. Sociology and scientism. The American quest for objectivity, 1880-1940, University of North Carolina Press.

/// Berthelot J.-M. 1996. Les vertus de lincertitude: le travail de l'analyse dans les sciences sociales, PUF.

/// Berthelot, J.-M. 2000. Introduction général, [w:] tegoż, Sociologie: épistémologie d'une discipline. Textes fondamentaux, De Boeck Université.

/// Berthelot J.-M. 2001a. Épistémologie des sciences sociales, PUF.

/// Berthelot J.-M. 2001b. Programmes, paradigmes, disciplines: pluralite et unite des sciences sociales, [w:] tegoż, Épistémologie des sciences sociales, PUF.

/// Berthelot J.-M. 2008. L'emprise du vrai. Connaissance scientifique et modernité, PUF.

/// Cuin Ch.-H. 2000. Ce que (ne) font (pas) les sociologues. Petit essai d'épistémologie critique, Librairie Droz.

/// Douglas M. 1978. Judgments on James Frazer, „Daedalus”, nr 107(4).

/// Dudek A. 2015. Jakub Karpinski jako bistoryk, „Stan Rzeczy”, nr 9, s. 165-171.

/// Eco U. 2007. Jak napisać prace dyplomowa. Poradnik dla bumanistów, tłum. G. Jurkowlaniec, Wydawnictwa Uniwersytetu Warszawskiego. 
/// Eisler J. 2015. Jakub Karpiński - pierwsøy peerelista, „Stan Rzeczy”, nr 9, s. $172-181$.

/// Fleck L. 1986. Ponstanie i rožwój faktu naukowego. Wprowadzenie do nauki o stylu myślowym $i$ kolektywie myślowym, tłum. M. Tuszkiewicz, Wydawnictwo Lubelskie.

/// Frege G. 2014. Myśl. Studium logiczne, [w:] tegoż, Pisma semantycz̨ne, tłum. B. Wolniewicz, Wydawnictwo Naukowe PWN.

/// Giddens A. 1974. Introduction, [w:] tegoż, Positivism and Sociology, Heinemann.

/// Grabowska M. 2006. Jakub, [w:] J. Karpiński, Wprowadzenie do metodologii nauk, spotecznych, WZPiZ.

/// Grabowska M., Szawiel T. [G.S.]. 1978. O ewolucji czy rewolucji Marka Tarniewskiego, „Zapis”, nr 6.

/// Gusfield J. 1976. The Literary Rhetoric of Science. Comedy and Pathos in Drinking Driver Research, „American Sociological Review”, vol. 41, nr 1.

/// Halfpenny P. 2005. Positivism, [w:] Encyclopedia of Social Theory, red. G. Ritzer, SAGE Publications, 572-576.

/// Hollis M. 1994. The Philosophy of Social Science. An Introduction, Cambridge University Press.

/// Jadacki J. 2013. Jakub Karpinski w kregu Sžoty Lwowsko-Warszawskiej, „Studia Socjologiczne”, nr 4(211).

/// Kanet R.E. 1982. Countdown. The Polish Upheavals of 1956, 1968, 1970, 1976, 1980... by Jakub Karpinski, recenzja w „The American Political Science Review", vol. 76, $\mathrm{nr} 4$.

/// Karpiński J. 1962. Postulat operacyjności definicji w naukach społecznych, „Studia Socjologiczne", nr 4.

/// Karpiński J. 1963. Socjologiczne i metodologiczne spojrzenie na socjologie, „Studia Socjologiczne", nr 4.

/// Karpiński J. 1965. Typy sporów na terenie nauk społecznych, „Studia Socjologiczno-Polityczne", nr 18.

/// Karpiński J. [Marek Tarniewski]. 1975. Ewolucja c₹y rewolucja, Instytut Literacki. 
/// Karpiński J. 1976. Schematy metodologiczne, „Studia Socjologiczne”, nr 1.

/// Karpiński J. 1985. Przyczynowość w badaniach socjologicznych, Państwowe Wydawnictwo Naukowe.

/// Karpiński J. 1988. Taternictwo niæinne, Instytut Literacki.

/// Karpiński J. 1989. Nie być w myśleniu postusznym. Ossowscy, socjologia, filozofia, Polonia Book Fund.

/// Karpiński J. 1992. Kultura i wielość rzeczy ywistości. Sžkice o kulturze, Wydawnictwo FIS.

/// Karpiński J. 2000. Pozytywizm, [w:] Encyklopedia socjologii, t. 3, red. W. Kwaśniewicz, Oficyna Naukowa.

/// Karpiński J. 2005. Ustrój komunistyczny w Polsce, WSPiZ.

/// Karpiński J. 2006. Wprowadženie do metodologii nauk społecznych, WZPiZ.

/// Kołakowski L. 1966. Filozofia pozytywistyczna. (Od Hume’a do Koła Wiedeńskiego), Państwowe Wydawnictwo Naukowe.

/// Kotarbiński T. 1986. Elementy teorii poznania, logiki formalnej $i$ metodologii nauk, Państwowe Wydawnictwo Naukowe.

/// Koźmiński A.K. 2005. Posłowie, [w:] J. Karpiński, Ustrój komunistyczny w Polsce, WZPiZ, tylna strona okładki.

/// Kripke S. 2001. Nazywanie a konieczność, tłum. B. Chwedeńczuk, Fundacja Aletheia.

/// Kula M. 2005. Prz̨edmowa, [w:] J. Karpiński, Ustrój komunistyczny w Polsce, WZPiZ.

/// Lakatos I. 1995. Pisma z filozofii nauk empirycznych, tłum. W. Sady, Wydawnictwo Naukowe PWN.

/// Latour B., Fabbri P. 1977. La rhétorique de la science. Pouvoir et devoir dans un article de science exacte, „Actes de la recherche en sciences sociales”, vol. 13.

/// Love A.C. 2009. Typology Reconfigured. From the Metaphysics of Essentialism to the Epistemology of Representation, „Acta Biotheoretica”, nr 57.

/// MacIntyre A. 2009. Trzy antagonistyczne wersje dociekań moralnych: etyka, genealogia i tradycja, tłum. M. Filipczuk, Wydawnictwa Akademickie i Profesjonalne. 
/// Madge J. 1964. The Origins of Scientific Sociology, The Free Press of Glencoe.

/// Mokrzycki E. 1990. Socjologia w filozoficznym kontekście, Wydawnictwo IFiS PAN.

/// Ossowski S. 1967. Nauki spoteczne w problematyce teorii kultury, [w:] tegoż, Drieła, t. 4: O nauce, Państwowe Wydawnictwo Naukowe.

/// Ossowski S. 1989. Problematyka swobody stowa w dyskusjach naukouych, [w:] Nie być w myśleniu postusznym. Ossowscy, socjologia, filozofia, Polonia Book Fund.

/// Popper K. 1999. Nedza bistorycyzmu, Wydawnictwo Naukowe PWN.

/// Popper K. 2002. Logika odkrycia nankowego, tłum. U. Niklas, Fundacja Aletheia.

/// Popper K. 2012. Wiedza obiektywna. Ewolucyjna teoria epistemologiczna, tłum. A. Chmielewski, Wydawnictwo Naukowe PWN.

/// Potter M. 2008. Wittgenstein's Notes on Logic, Oxford University Press.

/// Rosenberg A. 1995. Philosophy of Social Science, Westview Press.

/// Shapin S. 2010. Pump and Circumstance: Robert Boyle's Literary Technology, [w:] tegoż, Never pure. Historical studies of science as if it was produced by people with bodies, situated in time, space, culture, and society, and struggling for credibility and authority, Johns Hopkins University Press.

/// Sułek A. 2006. Styl socjologii Jakuba Karpińskiego, [w:] J. Karpiński, Wprowadzenie do metodologii nauk spotecznych, WSPiZ.

/// Toulmin S. 2003. The Uses of Argument, Cambridge University Press.

/// Wittgenstein L. 1974. Philosophical Grammar, Blackwell.

/// Wittgenstein L. 2004. Tractatus logico-philosophicus, tłum. B. Wolniewicz, Wydawnictwo Naukowe PWN.

/// Woleński J. 1985. Filozoficzna szkoła lwowsko-warszanskea, Państwowe Wydawnictwo Naukowe.

/// Wróblewski R. 2010. Charakterystyka lič̨bowa prasy niez̧ależnej z. lat 19761990, [w:] Papierem w system. Prasa drugoobiegowa w PRL, red. M. Marcinkiewicz, S. Ligarski, Instytut Pamięci Narodowej - Komisja Ścigania Zbrodni przeciwko Narodowi Polskiemu. Oddział w Szczecinie. 


\section{/// Abstrakt}

Jakub Karpiński (1945-2003) był znakomitym polskim metodologiem socjologii, prowadzacym badania z zakresu epistemologii nauk społecznych w ramach paradygmatu lwowsko-warszawskiej szkoły filozofii. Jednocześnie stał się jednym z pierwszych i najważniejszych historyków i socjologów systemu komunistycznego w Polsce. Jego socjologiczne opus magnum w badaniach nad komunizmem stanowi książka Ustrój komunistyczny $w$ Polsce. Celem artykułu jest przedstawienie projektu socjologii zrekonstruowanego na podstawie tego dzieła w wymiarze retoryki, epistemologii i ontologii. Ukazane zostają racje społeczne i kognitywne, które sprawiły, że program Karpińskiego nigdy nie stał się postępowy w sensie Imrego Lakatosa. Autor stawia pytanie o paradoks: dlaczego świetny metodolog nie stał się równie wybitnym empirykiem?

Słowa kluczowe:

historia polskiej socjologii, filozofia nauk społecznych, pozytywizm

\section{/// Abstract}

Jakub Karpiński (1945-2003) was an outstanding Polish methodologist, conducting research in the field of epistemology of the social sciences within the paradigm of the Lvov-Warsaw school of philosophy. At the same time he became one of the first historians and sociologists of the communist system in Poland. His book Ustrój komunistyczny w Polsce (The Communist Regime in Poland) was his sociological opus magnum. The aim of this paper is to explore his sociology project which has been divided into three aspects: rhetoric, epistemology and ontology. It examines the social and cognitive reasons for the fact that Karpiński's research programme never became progressive in accordance with Imre Lakatos's seminal concept. The author raises the question: why didn't brilliant methodologist become an equally bright empirical researcher?

Keywords:

history of Polish sociology, philosophy of the social sciences, positivism 